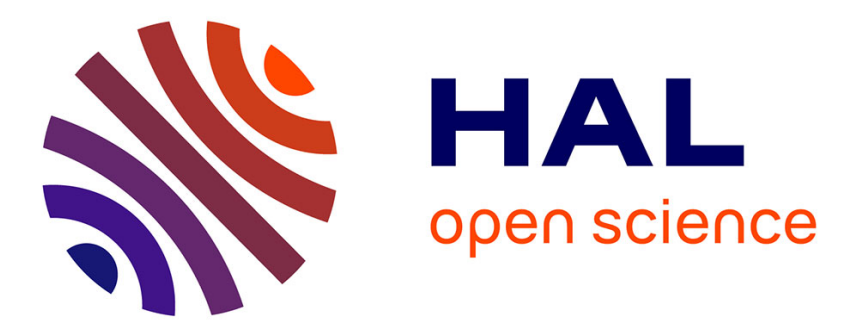

\title{
Optimization of DC reactive magnetron sputtering deposition process for efficient YSZ electrolyte thin film SOFC
}

\author{
Hervé Hidalgo, Anne-Lise Thomann, Thomas Lecas, Julien Vuillet, K. \\ Wittman-Teneze, David Damiani, Eric Millon, Pascal Brault
}

\section{To cite this version:}

Hervé Hidalgo, Anne-Lise Thomann, Thomas Lecas, Julien Vuillet, K. Wittman-Teneze, et al.. Optimization of DC reactive magnetron sputtering deposition process for efficient YSZ electrolyte thin film SOFC. Fuel Cells, 2013, 13, pp.279-288. 10.1002/fuce.201200125 . hal-00757718

\section{HAL Id: hal-00757718 https://hal.science/hal-00757718}

Submitted on 27 Nov 2012

HAL is a multi-disciplinary open access archive for the deposit and dissemination of scientific research documents, whether they are published or not. The documents may come from teaching and research institutions in France or abroad, or from public or private research centers.
L'archive ouverte pluridisciplinaire HAL, est destinée au dépôt et à la diffusion de documents scientifiques de niveau recherche, publiés ou non, émanant des établissements d'enseignement et de recherche français ou étrangers, des laboratoires publics ou privés. 


\title{
Optimization of DC reactive magnetron sputtering deposition process for efficient YSZ electrolyte thin film SOFC
}

\author{
H. Hidalgo ${ }^{1}$, A.-L. Thomann ${ }^{1}$, T. Lecas ${ }^{1}$, J. Vulliet ${ }^{2}$, K. Wittmann-Teneze ${ }^{2}$, D. Damiani ${ }^{2}$, E. Millon ${ }^{1}$, P. Brault ${ }^{1, *}$ \\ ${ }^{1}$ Groupe de Recherches sur l'Energétique des Milieux Ionisés (GREMI), UMR 7344 CNRS-Université \\ d’Orléans, 45067 Orléans, France \\ ${ }^{2}$ CEA, DAM, Le Ripault, F-37260 Monts
}

[*] Corresponding Author : pascal.brault@univ-orleans.fr

\begin{abstract}
Yttria-stabilized zirconia (YSZ, $\mathrm{ZrO}_{2}: \mathrm{Y}_{2} \mathrm{O}_{3}$ ) thin films were deposited by reactive DC magnetron sputtering with a high deposition rate from a metallic target of $\mathrm{Zr} / \mathrm{Y}$ in an argon/oxygen atmosphere. Plasma parameters and composition analysis of the gas phase reveal that the sputtering process in the "compound" mode is reached for a $2.5 \mathrm{sccm}$ oxygen flow rate. Deposition onto silicon in "metal" mode at a flow rate close to the transition, allows obtaining at very high deposition rates $\left(>10 \mu \mathrm{m} \cdot \mathrm{h}^{-1}\right)$ a compact columnar stoichiometric crystallized YSZ film. When deposited on NiO-YSZ commercial anode, the obtained coatings show the same properties. In spite of the complexity of the substrate (roughness and porosity), a compact and conformed layer was formed. Annealing treatments in air or hydrogen do not significantly alter the structure of the layers. Electrochemical test at $850^{\circ} \mathrm{C}$ with a screen-printed LSM $\left(\mathrm{LaSrMnO}_{3}\right)$ cathode exhibits a satisfying gastightness $(\mathrm{OCV}=900 \mathrm{mV})$ and a maximum power density of $350 \mathrm{~mW} . \mathrm{cm}^{-2}$.
\end{abstract}

Keywords: Anode-Supported SOFC, Thin films, magnetron sputtering, YSZ, electrolyte

\section{Introduction}

Fuel cells are one of the most effective techniques to convert fuel (hydrogen, syngas...) into electricity. Among the different technologies [1], solid oxide fuel cells (SOFC) exhibit a high tolerance to fuel impurities and the possibility to combine production of electricity and heat [2]. The most common ceramic used as SOFC electrolyte is yttria stabilized zirconia - xYSZ, $\left(\mathrm{ZrO}_{2}\right)_{1-\mathrm{x}}:\left(\mathrm{Y}_{2} \mathrm{O}_{3}\right)_{\mathrm{x}}$ - which presents an optimal ionic conduction in the chemical composition range: 8 YSZ-12YSZ [3]. Nevertheless, high working temperatures $\left(800-1000^{\circ} \mathrm{C}\right)$ are needed to ensure sufficiently high internal conductivity, but leads to thermal or mechanical degradation of the cell materials.

An effective way to increase the reliability and to lower the cost of SOFC systems would be to reduce the size of the cell and particularly the electrolyte thickness. In that aim, $\mu$-SOFC devices were developed [4] with an electrolyte thickness of about $1 \mu \mathrm{m}$. 
In order to ensure that the total internal resistance of a fuel cell is sufficiently small, the ASR (area specific resistivity: ratio between the thickness and the conductivity of the layer) of the electrolyte must be lower than $0.15 \Omega \cdot \mathrm{cm}^{2}[5]$.

As at intermediate temperature $\left(600^{\circ} \mathrm{C}\right)$, the electrolyte layer conductivity has to be higher than $10^{-2} \mathrm{~S} . \mathrm{cm}^{-1}$, the classical $100 \mu \mathrm{m}$-thick $8 \mathrm{YSZ}$ layer can not be used. In this range of temperature, the thickness of an YSZ electrolyte layer should be lowered down to $10 \mu \mathrm{m}$.

Conventional firing ceramic processing techniques such as screen printing, and tape casting lead to prepare 10$100 \mu \mathrm{m}$ thick YSZ electrolyte layers. Nevertheless, there are works showing that screen-printing of YSZ electrolytes for SOFC is possible with thicknesses of around 10 micrometers and below[6-7]. Among the alternatives, vacuum thin films technologies are advanced methods that allow thin layer $(0.1-20 \mu \mathrm{m})$ synthesis, avoiding a high temperature sintering step $\left(>1000^{\circ} \mathrm{C}\right)$ [8]. Plasma magnetron techniques [9] are very weakly polluting — neither toxic gases nor liquid emissions — industrial methods. By these last techniques, uniform thin films can be obtained over large areas at quite low temperature $\left(<600^{\circ} \mathrm{C}\right)$. Properties of the films can be monitored in wide ranges by the choice of the deposition conditions.

Previous investigations have shown that dense, gastight, electronic insulating and ionic conductor YSZ thin film can be successfully deposited by DC magnetron sputtering from metallic targets $[10,11]$ or by RF magnetron sputtering of a ceramic YSZ target [12]. Ni-YSZ anode [13] and LSM cathode [14] can also be deposited by these techniques.

In the present work, a study of the plasma according to the target voltage and the oxygen flow rate is first made to evidence and control the metal and compound sputtering modes. $10 \mu \mathrm{m}$-thick YSZ films are grown on (100) silicon single crystal and commercial NiO-YSZ anode substrates. Deposition conditions and substrate nature which influences the film properties are studied and discussed. Finally, the fuel cell performance of YSZ films showing the most promising properties are evaluated through electrochemical tests.

\section{Experimental}

\subsection{Magnetron sputtering device}

Magnetron sputtering experiments were performed in a stainless steel $(\varnothing=15 \mathrm{~cm} ; \mathrm{h}=13 \mathrm{~cm})$ deposition chamber (Figure 1). Before deposition, the chamber was evacuated down to $10^{-4} \mathrm{~Pa}$ using a turbo molecular pump; the deposition pressure was 1.2 Pa. Argon (Air Liquide 99.9995\%) and oxygen (Air Liquide 99.9995\%) flow rates were monitored by two mass flow controllers and entering the chamber by the same tube. A vacuum-melted metallic zirconium-yttrium target (82/18 wt\%, NEYCO 99.5\%) was clamped to a 2"- planar magnetron (Thin Film Consulting ION'C-2") powered by a direct current power supply (Advanced Energy Pinnacle+). The current intensity was set at $1 \mathrm{~A}$, which corresponds to a specific power density close to $12 \mathrm{~W} . \mathrm{cm}^{-2}$. This device was optimized to enhance the deposition rate by using a $5 \mathrm{~cm}$-long chimney to avoid deposition everywhere in the chamber. The samples were fixed with silver paste on a substrate holder located $7 \mathrm{~cm}$ away from the cathode. During deposition, the surface temperature of the sample was not regulated. In this study, only the influence of the oxygen flow rate will be considered.

\subsection{Process and characterizations of thin films}


The film thickness and the surface morphology were determined by scanning electron microscopy (SEM, Carl Zeiss supra-40 FEG-SEM) by using the secondary electron mode detection. The film composition was studied by energy dispersive X-ray spectroscopy (EDS, Bruker XFlash Detector 4010 coupled with the SEM) and by Rutherford Backscattering Spectroscopy (RBS) using a $2 \mathrm{MeV}$ He ion beam from a Van de Graaf accelerator (facility of CEMHTI laboratory, Orléans). RBS is used to evaluate the global content of heavy elements in the thin films (zirconium and yttrium). However, the molar mass of the two elements are too close to distinguish $\mathrm{Zr}$ and $\mathrm{Y}$ contribution by RBS. EDS is thus used to estimate the ratio between zirconium and yttrium. The concentration of oxygen is measured by Nuclear Reaction Analysis (NRA) from the ${ }^{16} \mathrm{O}(\mathrm{d}, \alpha){ }^{16} \mathrm{~N}$ reaction. The calibration is carried out using a $\mathrm{Ta}_{2} \mathrm{O}_{5}$ reference sample (International Standard Reference). RBS and NRA spectra were simulated with the SIMNRA software [15]. The control of phases and their preferred orientation regarding the surface substrate were performed by $\theta-2 \theta$ X-Ray Diffraction (XRD) using the $\mathrm{Cu} K \alpha$ radiation $(\lambda=1.54056 \AA)$ in the $25^{\circ}-62^{\circ} 2 \theta$ range.

Analysis of the reactive phase composition was carried out by Optical Emission Spectroscopy (OES) above the substrate holder using an optical fiber through the porthole at the entrance of argon gas (Figure 1). A spectrometer BWtek BCT110E (1 nm resolution) records the emission spectrum of the plasma in the range $300-900 \mathrm{~nm}$.

The electrochemical properties were studied on single cell assembly according to Figure 2. The experimental device allows feeding the cell with water and hydrogen diluted with nitrogen at the anode side of the cell, and an air supply at the cathode side. Hydrogen causes the reduction of nickel oxide in the cermet during early operation of the cell. Finally, specific wires dedicated to voltage measurements (no current flow) were used as electrical connectors. The anode side was sealed contrary to the cathode one since the enhancement of unused oxygen was not under investigation. A load $\left(200 \mathrm{~g} . \mathrm{cm}^{-2}\right)$ was applied to the cell to ensure a proper electrical contact. The temperature of the system was raised to $850^{\circ} \mathrm{C}$ at a rate of $0.5^{\circ} \mathrm{C} \cdot \mathrm{min}^{-1}$ under nitrogen atmosphere. Hydrogen was then gradually introduced up to $12 \mathrm{NmL} \cdot \mathrm{min}^{-1} \cdot \mathrm{cm}^{-2}$ to ensure the reduction of the cermet and an air flow of $12 \mathrm{NmL} \cdot \mathrm{min}^{-1} \cdot \mathrm{cm}^{-2}$ is set. Prior to the characterization of the cell as a function of various parameters, a quick test at $850{ }^{\circ} \mathrm{C}$ was performed in order to check the system (integrity of the cells, full reduction of cermet, gastightness...).

Whereas a commercial NiO-YSZ plate will be used as anode, two types of cathodes were tested:

(a) $2 \mu \mathrm{m}$-thick porous platinum deposited by screen painting at room temperature and annealed at $900^{\circ} \mathrm{C}$ for 30 min: this platinum reference cathode is only an electronic conductor; the oxygen dissociation occur only at the contact line between the platinum surface and the YSZ electrolyte one;

(b) $38 \mu \mathrm{m}$-thick porous double layer lanthanum strontium manganite (LSM): this real SOFC cathode is composed by a composite YSZ(50\%)/LSM(50\%) porous layer $(32 \mu \mathrm{m}$, electrolyte side) on a pure LSM layer $\left(16 \mu \mathrm{m}\right.$, current collector side) which requires a $1300^{\circ} \mathrm{C}$ sintering step of all the cell. LSM (purchased to Fuel Cell Materials) has the composition $\mathrm{La}_{0.8} \mathrm{Sr}_{0.2} \mathrm{MnO}_{3}$. Contrary to platinum, LSM is a mixed ionic electronic conducting ceramic which leads to oxygen reduction reaction on all the surface of the LSM porous layer [16].

\section{Results and Discussion}

\subsection{Plasma analysis}


In order to characterize the deposition conditions, it is interesting to study the behavior of the plasma when the experimental parameters (oxygen flow rate) are modified.

The plasma light emission was observed by the lateral window used for OES. In the absence of oxygen, the plasma is confined within the chimney near the cathode and only illuminates the exposed face of the substrate holder. The introduction of a low oxygen flow induces a change in the plasma color. For high oxygen flow rates, the plasma completely changes and is no longer localized in the chimney vicinity, but fills the entire reactor. The oxygen flow thus plays a major role on the expansion of the plasma emitting zone.

While the process is current regulated, the voltage varies with plasma experimental conditions. Figure 3 presents the evolution of the cathode voltage and of the pressure measured in the chamber with respect to the oxygen flow rate while maintaining the same pumping speed. When the oxygen flow rate increases, the target voltage undergoes a small increase up to a critical point. At the same time, the pressure remains stable in the chamber. For a flow rate of $2.5 \mathrm{sccm}$, the voltage sharply rises and the pressure reaches a value slightly lower than that measured in the absence of the plasma (dotted line). Beyond $2.5 \mathrm{sccm}$, the voltage increases linearly. The pressure undergoes the same increasing as it would do without plasma. For a decreasing oxygen flow rate, a transition of the same type occurs but at much lower flow rate value $(0.8 \mathrm{sccm})$ and the values before the cycle are retrieved. A similar hysteresis behavior has already been described by Venkataraj [17] in reactive sputter deposition of YSZ for the same oxygen flow rates.

This highlighted hysteresis is characteristic of a reactive sputtering process [18]. Initially, oxygen which has a very strong chemical affinity for metals is introduced in an amount sufficiently low that it is completely gettered on the reactor walls, the sputtered target and the freshly deposited metallic atoms. So the measured pressure remains unchanged. The gas phase, mainly consisting in argon, is unchanged: the plasma characteristics and the target voltage do not evolve. This is known as "metal" sputtering mode. When the oxygen amount is increased, this behavior remains until the metallic vapor / surface atoms cannot getter all the oxygen any more. Beyond, oxygen can completely cover the metallic sputter target and poisons it, forming insulating $\left(\mathrm{ZrO}_{2}\right.$ and $\left.\mathrm{Y}_{2} \mathrm{O}_{3}\right)$ oxides. Thus the sputter voltage increases in order to maintain the current and the unadsorbed oxygen causes a sudden increase of the pressure. Theses conditions are known as "compound" sputtering mode. As the secondary electron emission coefficient is larger for the zirconium oxide than for pure metal [18], the measured voltage for a given current is expected to be higher in absolute value and the efficiency of the sputtering is strongly reduced. Reducing the oxygen flow, the "compound" mode is maintained down to the point for which all the gettered oxygen is removed from the sputter target surface to return to "metal" mode.

An optic fiber collects the signal from the plasma $1 \mathrm{~cm}$ above the substrate holder. Four neutral excited species (Ar, Zr, Y and O) were detected respectively at $750 \mathrm{~nm}, 481 \mathrm{~nm}, 407 \mathrm{~nm}$ and $777 \mathrm{~nm}$ and the $\operatorname{Ar}^{+}$excited ion at $488 \mathrm{~nm}$. No molecular species have been detected. Figure 4(a) presents the evolution of the $750 \mathrm{~nm}$ argon line intensity as a function of oxygen flow rate. The two sputtering modes are easily observable: in "metal" mode, the argon intensity is weak, whereas in "compound" mode, intensity is ten times larger. It is known that the upper level of this argon line is populated by electronic collisions from the ground state level. The evolution of this line is therefore representative of the energetic state of the plasma, i.e. the electron energy distribution function. Thus, the intensity ratio between lines of the other elements and the $\operatorname{Ar}(750 \mathrm{~nm})$ one allows, in a first approximation, to get rid of the evolution of plasma parameters (electron density and electron temperature) in different experimental conditions. 
Figure 4 (b, c, d) represents the evolution of the intensity ratios $\left(\mathrm{Zr} / \mathrm{Ar}\right.$ and $\mathrm{Y} / \mathrm{Ar}, \mathrm{O} / \mathrm{Ar}$ and $\left.\mathrm{Ar}^{+} / \mathrm{Ar}\right)$ for all the detected species with respect of the oxygen flow rate. In the "metal" mode, the ratios of zirconium and yttrium tend to increase with the introduction of oxygen up to the transition. On the contrary, in "compound" mode, no lines were detected. The ratio of atomic oxygen follows a different trend: atomic oxygen is not detected in "metal" mode. After the transition, its value sharply increases and then linearly with the oxygen flow rate. When the oxygen flow rate decreases, the atomic oxygen ratio decreases linearly until the transition beyond which atomic oxygen becomes undetectable. This evolution is similar to that of the pressure in the chamber and shows that, in "metal" mode, atomic oxygen concentration is very low in the gas phase, unlike in the "compound" mode. From Figure 4d, it appears that $\mathrm{Ar}^{+}$ions are only detected in "compound" mode. This proves that — as can also be deduced from the increase of the $750 \mathrm{~nm}$ argon line intensity (Figure 4a) and the delocalization of the plasma far from the target — the plasma created in "compound" mode is very different from that obtained in mode "metal". It is more energetic around the substrate holder.

The plasma analysis clearly evidences both sputtering modes. For an oxygen flow rate below $2.5 \mathrm{sccm}$, the plasma is localized near the cathode. Metallic elements are sputtered away from the target and atomic oxygen is not detected in the gas phase: the sputtering is in "metal" mode. For a oxygen flow rate beyond $2.5 \mathrm{sccm}$, in "compound" mode, the plasma is not confined near the target but fills the whole chamber. Atomic oxygen is present in the gas phase while the metal species ( $\mathrm{Zr}$ and $\mathrm{Y}$ ) become undetectable; in this mode, the surface of the metallic target is fully oxidized and the argon ions sputter $\mathrm{ZrO}$ and $\mathrm{YO}$ [19]. Unfortunately, $\mathrm{ZrO}$ and $\mathrm{YO}$ molecular bands (respectively at $482.8 \mathrm{~nm}$ and $613.2 \mathrm{~nm}$ ) could not be detected by our optical detection system.

\subsection{Deposition on silicon}

The properties of the YSZ films deposited by magnetron sputtering have been studied by using (100) silicon wafer substrates which are more suitable for surface analyses.

The conditions of deposition, for studying the influence of oxygen flow rate on the investigated films, have been chosen from the electrical characterization of the plasma. Four conditions were selected: one without oxygen, two in "metal" mode (1 and $2 \mathrm{sccm})$ and one in "compound" mode $(3.5 \mathrm{sccm})$. The argon flow rate is maintained at $4 \mathrm{sccm}$. In "metal" mode, the deposition rate (Figure 5) reaches $15 \mu \mathrm{m} . \mathrm{h}^{-1}$; which is higher than reported in literature $[20,21]$ because of the high power density applied on the target $\left(12 \mathrm{~W} . \mathrm{cm}^{-2}\right)$ and the close vicinity to the substrate.

The increase of oxygen flow rate until $2 \mathrm{sccm}$ tends to enhance the deposition rate. This trend has already been observed in magnetron sputtering of various metals in oxygen atmosphere and is usually attributed to the so called gettering effect [22, 23]. Indeed, before the transition, i.e. before the target gets fully poisoned, the growing film adsorbs oxygen atoms and the deposited thickness is higher than for a pure metallic film [19, 24]. However, this phenomenon can be not significant for $\mathrm{ZrO}_{2}$ deposition [25]. In the "compound" mode, on the contrary, the deposition rate becomes very low $\left(0.8 \mu \mathrm{m} \cdot \mathrm{h}^{-1}\right)$ and which is not suitable for the deposition of a few micrometer thick films required for the SOFC application.

The morphology of the films was studied by surface and fracture cross-section (Figure 6) SEM observation. The coating obtained without oxygen presents very fine columns. On the surface, no visible structures are identified. The addition of $1 \mathrm{sccm}$ of oxygen induces a significant change in the film morphology: in cross-section, the film exhibits a more compact structure while the surface is composed of grains smaller than $100 \mathrm{~nm}$. By increasing 
the oxygen flow rate, the structure becomes columnar with a larger column width. The surface topology is characterized by angular-shape grains of about $200 \mathrm{~nm}$ width. Film obtained in "compound" mode $(3.5 \mathrm{sccm})$ is not thick enough to determine its cross-section morphology by SEM. On the surface, the structure appears smoother and numerous small grains are distinguishable.

Figure 7 presents the evolution of the elementary composition of the thin film with respect of the oxygen flow rate. The yttria substitution rate of zirconia (xYSZ) is obtained from the proportion of $\mathrm{Zr}$ and $\mathrm{Y}$ in the thin films and the oxidation level $(\Omega)$ of xYSZ is calculated from the ratio of oxygen amount in the film to the oxygen amount expected if the metallic elements were fully oxidized from the following equations:

$$
\begin{gathered}
x=\frac{[Y]}{2 \cdot[\mathrm{Zr}]+[Y]} \times 100 \\
\Omega=\frac{[O]}{2 \cdot(1-x)+3 \cdot x}=\frac{[O]}{2+x}
\end{gathered}
$$

Equation 1

Equation 2

For the film obtained in pure argon atmosphere, the $\mathrm{x}$ parameter reaches 13.6 which corresponds to the value expected in the sputtered particles flux — calculated with the TRIM/SRIM software [26] — for the bombardment of the $\mathrm{Zr} / \mathrm{Y}$ target by $300 \mathrm{eV}$ argon ion $\left(\mathrm{x}_{\text {sputt }}=13.6\right)$.

In "compound" mode deposition, the $x$ parameter of the coating is lower $\left(x_{3.5 ~ s c c m}=9.7\right)$ than in oxygen free deposition expressing a lowered yttrium content. This value is in agreement with the $x$ parameter calculated from the measured target composition ( $\mathrm{x}_{\text {target }}=9.9$ ).

As the standard free energy of formation of yttrium oxide $\left(-1206 \mathrm{~kJ} \cdot \mathrm{mol}^{-1} @ 323 \mathrm{~K}\right)$ is lower than that of zirconium oxide (-1037 kJ.mol $\left.{ }^{-1} @ 323 \mathrm{~K}\right)$ [27], the yttrium atoms will be preferentially oxidized compared to zirconium atoms. The sputtering yield being lower for yttria than for metallic yttrium, in presence of oxygen, the particle flux sputtered from the target contains less yttrium atoms, whereas the zirconium quantity remains almost constant. This results in lowering of yttrium content in the film.

When the target is fully oxidized (in "compound" mode), oxidized species ( $\mathrm{ZrO}$ and $\mathrm{YO}$ ) are sputtered [19]. Their sputtering yields are weak and close to each other: the composition in the metallic element of the target is thus kept in the film.

It is important to note that, whatever the oxygen flow rate used, the composition of films is in the range 8YSZ12YSZ for which the theoretical ionic conduction of cubic YSZ is optimal [3].

Regarding the oxidation level (Figure 7b), the films are found totally metallic in the absence of oxygen. They become fully oxidized for a oxygen flow rate above $2 \mathrm{sccm}$. At $1 \mathrm{sccm}$, the oxygen amount adsorbed at the surface of the growing film is low and a $30 \%$ lack of oxygen is measured.

Figure 8 includes X-ray diffraction diagrams in $\theta-2 \theta$ geometry of thin films deposited in "metal" mode. The film in "compound" mode was not thick enough to obtain a usable signal in this XRD configuration.

When the deposition process occurs in pure argon atmosphere, only two sharp peaks at $30.9^{\circ}$ and $33.9^{\circ}$ are detectable. They can be attributed respectively to the $(10 \overline{1} 0)$ and (0002) diffraction planes of an hexagonal solid solution of yttrium in zirconium (Zr:Y). The film presents a strong (0002) preferred orientation. In the case of substitution solid solution, the Vegard's rule [28] allows to calculate the yttrium content in the solid solution $\mathrm{Zr}: Y$ from the position of diffraction peaks. Pure zirconium (JCPDS \#05-0665) and yttrium (JCPDS \#33-1458) 
both crystallize in the close-packed hexagonal arrangement and form a complete solid solution [29]. Taking into account the lattice parameters of the pure metals [29], Vegard's rule gives a composition of 76/24 $\left(\mathrm{x}_{0 \text { sccm_XRD }}=13.6\right)$ which is what has been measured on the deposited film by chemical analysis (EDS, RBS). The mean grain size determined by the Scherrer formula from the (0002) XRD peak is estimated at about $50 \mathrm{~nm}$.

For $1 \mathrm{sccm}$ of oxygen, only one peak $\left(33.8^{\circ}\right)$ remains on the diffraction diagram. Furthermore, its intensity is 400 times lower than the peak observed at this angle for the film synthesized without oxygen, and its integral width is 16 times larger: the film presents a lower ordered structure.

This peak can be indexed either as the (0002) plane of the Zr:Y solid solution, or as the (002) plane of the tetragonal zirconia (JCPDS \#42-1164). Due to its large width and the absence of any other peaks, it is not possible to determine which phase is present; both of them could co-exist.

For $2 \mathrm{sccm}$ of oxygen, the diffraction pattern is completely different. The four well-marked peaks $\left(30.0^{\circ}\right.$, $34.9^{\circ}, 50.0^{\circ}$ and $59.5^{\circ}$ ) can be attributed to respectively (111), (200), (220), (311) planes of the substitution solid solution that can be formed between cubic zirconia (JCPDS \#49-1642) and cubic yttria (JCPDS \#43-0661). From the lattice parameter evolution as a function of the yttria content [30], the Vegard's rule for the solid solution $\mathrm{ZrO}_{2}: \mathrm{Y}_{2} \mathrm{O}_{3}$ allows to deduce that the film is composed of $11 \%$ yttria doped zirconia $\left(\mathrm{x}_{2 \mathrm{sccm} \_\mathrm{XRD}}=11\right)$, which again is in agreement with results from chemical analysis (EDS, RBS) of the films.

The elementary composition of the films was determined by 3 independent methods: (1) calculation estimation from the knowledge of the sputtering process; (2) direct measurements by coupling analysis techniques (NRA, RBS and EDS); (3) estimation by the Vegard's rule from XRD measurement. It is important to note that for the three studied samples, the three methods lead to the same value of metallic element ( $\mathrm{Zr}$ and $\mathrm{Y}$ ) content.

The raise of $32 \%$ of the deposition rate observed in "metal" mode (Figure 5) can be compared with the $28 \%$ increase of the molar volume from the $\mathrm{Zr}$ :Y metallic solid solution to the 11YSZ oxide solid solution due to the incorporation of oxygen atoms in the Zr:Y lattice.

The oxygen flow rate is a very important parameter to monitor the properties of YSZ deposited by magnetron sputtering from a metallic target: it should be high enough to oxidize all the metallic sputtered particles reaching the substrate and to stabilize a well-ordered crystalline oxide phase but it must not exceed the value at the transition in order to avoid entering the "compound" regime where the deposition rate is very low. In the intermediate range (at $1 \mathrm{sccm}$ ), oxygen incorporated in the film impedes the formation of an ordered solid solution and does not allow the crystallization of a stable oxide phase.

The film deposited on silicon wafer with a oxygen flow rate of $2 \mathrm{sccm}$ fulfills to all the requirements for SOFC electrolyte application [3]: the composition is in the range 8YSZ-12YSZ (11YSZ); the material is crystallized in the cubic phase; no porosity was detected by SEM observation (the electrolyte must be gastight); the deposition rate allows the synthesis of a $5 \mu \mathrm{m}$ thick layer in a reasonable time (20 min).

\subsection{Coating on commercial anode}

In the optimized experimental conditions determined on silicon, a $1 \mu \mathrm{m}$ thick coating was achieved on a real commercial anode. This substrate is a NiO-YSZ composite which has a surface pores of about $1 \mu \mathrm{m}$ in diameter and a marked roughness $\left(R_{\max }=2 \mu \mathrm{m}\right)$. This anode is composed of two layers: (1) a $200 \mu \mathrm{m}$ thick porous holder layer for the mechanical strength of the anode and the good flow of gases - called ACC (anode current 
collector) — and (2) a denser layer (porosity: 5\%) — called AFL (anode functional layer) — with a higher nickel loading for a better catalysis of the hydrogen oxidation, and a better conduction of released electrons. The first use of the anode in high temperature reducing atmosphere leads to the reduction of $\mathrm{NiO}$ into Ni. It leads to a gaseous release of $\mathrm{H}_{2} \mathrm{O}$ and a volume reduction of $\mathrm{NiO}$ grains. These two phenomena may be a damaging source for the electrolyte layer.

The behavior of the YSZ film deposited on this anode must be tested in reducing, but also oxidizing atmosphere. Indeed, in the operating conditions, deposited side of the coating undergoes reducing atmosphere, whereas open side is in contact with air atmosphere.

Thin film analysis first shows that the thickness of the film deposited on the anode is the same as that on silicon. The cross-section structures are also preserved: dense columns are present on the rough substrate that follows the morphology of the surface. The angular-shaped grains already evidenced on silicon (Figure 6) are also observed on the NiO-YSZ substrate (Figure 9). EDS and XRD analyses show that the elemental composition and crystallinity of the film are the same as for Si supported film. This indicates that the sticking coefficient of the metallic elements is quite the same on both substrates. Moreover, the oxidizing process taking place on the substrate surface is not significantly modified by the morphology or nature of the substrate.

On large-scale SEM images (not shown here), one can note that the porosity of the substrate is locked by the film. Moreover, as reported by Wang [31] and Coddet [32] on AFL coated anode substrate, no obvious intercolumn porosity is evidenced.

Annealing in air was performed at $600^{\circ} \mathrm{C}$ for $90 \mathrm{~min}$. Neither peelings nor cracks of the coating were observed. The surface of the film is slightly smoother than before annealing. A sintering of the columns took place inducing densification of the film (Figure 9). Neither modification of elemental composition nor of the crystallinity are observed.

Annealing in hydrogen $\left(5 \% \mathrm{H}_{2}\right.$ in $\left.\mathrm{Ar}\right)$ was performed at $700^{\circ} \mathrm{C}$ for $24 \mathrm{~h}$. The reduction of $\mathrm{NiO}$ grains of the substrate led to the increase of the porosity in the "active" layer of the anode. The behavior of the film during $\mathrm{H}_{2}$ treatment is rather the same as for air treatment, although it might be more stressful due to $\mathrm{NiO}$ volume reduction and $\mathrm{H}_{2} \mathrm{O}$ outgassing. Nevertheless, neither cracks nor peelings are detected and the morphology is unchanged.

All the above observations prove that YSZ films synthesized by reactive magnetron sputtering in optimum deposition conditions ( 2 sccm oxygen flow rate) would be good candidates for SOFC electrolyte layer. To check this assumption, electrochemical tests have been performed on film deposited onto a NiO-YSZ anode.

\subsection{Fuel cell tests}

$5 \mu$ m-thick YSZ electrolyte was deposited by magnetron sputtering on the H.C. Starck commercial NiO/YSZ anode in the optimal deposition conditions. The two SOFC configurations with the different cathodes (platinum and lanthanum strontium manganite) as described in the experimental section are represented in the Figure 2.

The $900^{\circ} \mathrm{C}$ electrolyte layer (Figure 10a) presents a classical compact columnar structure, the $1300^{\circ} \mathrm{C}$ annealing (Figure 10b) leads to a sintering of the columns to grains with the formation of closed porosity between the grains. Neither cracks nor crossing porosity are observed.

These cells were evaluated by their $\mathrm{I}-\mathrm{V}$ characteristics at $800^{\circ} \mathrm{C}$ and $850^{\circ} \mathrm{C}$ (Figure 11 ). Air was used at the cathode side, whereas hydrogen diluted in nitrogen is introduced at the anode side. 
Whatever the tested configurations, the voltage measured in open circuit (OCV) is always close to $1000 \mathrm{mV}$ (Table 1). These values are slightly lower than the state-of-art $(1110 \mathrm{mV})$ probably due to tiny leak in the electrolyte. Nevertheless, it is high enough to test the behavior of the electrolyte under charge. The close values of OCV found for both $\left(900\right.$ and $\left.1300^{\circ} \mathrm{C}\right)$ annealing treatments indicate that they do not provide any enhancement of the gastightness of the electrolyte.

The efficiency of the cell was strongly dependent on the test temperature (Table 1). A rise of $50^{\circ} \mathrm{C}$ led to increase the maximum power (Pmax) and the current density $(\mathrm{j} @ 700 \mathrm{mV})$ obtained at $700 \mathrm{mV}$ by $50 \%$. For Pt cathode, the performances of the cell are low at $850^{\circ} \mathrm{C}$ and no recordings were done at lower temperature. The use of LSM cathode enhanced the efficiency by doubling the maximum reached power (Pmax) and a corresponding fourfold increase in power density. This phenomenon is due to the increasing of the Three-PhaseBoundaries (TPB) number by changing the cathode: for platinum, they are located only at the point of contact between platinum and electrolyte whereas, for real LSM cathode the mixed porous LSM/YSZ layer allows to delocalize the reduction reaction all along the cathode surface in contact with the gas.

The area specific resistivity (ASR) deduced at $700 \mathrm{mV}$ for Pt cathode cell (Table 1) is too high for a use as SOFC. ASR is strongly promoted by the high temperature operation and become closer to the target value of $0.15 \Omega . \mathrm{cm}^{-2}[5]$.

These results are slightly lower than those of Coddet et al. [32] with a YSZ magnetron sputtering SOFC: they obtained a current density of $800 \mathrm{~mA} \cdot \mathrm{cm}^{-2}$ at $700 \mathrm{mV}$ for a $6 \mu \mathrm{m}$ thick YSZ electrolyte but with a even more efficient cathode made in LSC (lanthanum strontium colbaltite). Nevertheless, it can be compared with thin film electrolyte technologies SOFC (100-1000 mA.cm $\left.{ }^{-2}\right)$ but remains lower than SOFC obtained by traditional firing methods (1000-1400 mA.cm ${ }^{-2}$ ) and has efficiency close to commercial H.C. Starck ESC2 fuel cell (500 mA.cm-2@700mV). On the other hand, Nédélec et al. [33] have reached a current density of $1750 \mathrm{~mA} . \mathrm{cm}^{-2}$ and an ASR of 0.17 for a $2 \mu \mathrm{m}$ DC magnetron sputtered YSZ. Also they used an improved LSCF cathode and add RF biasing of the substrate for getting denser electrolyte. All these improvement can allow better performances than reached in the present study.

\section{Conclusion}

Yttria stabilized zirconia coatings were obtained by reactive magnetron sputtering from a metallic target of $\mathrm{Zr} / \mathrm{Y}$ in an argon/oxygen atmosphere. Plasma parameters and composition of the gas phase analyses show the presence of a transition from "metal" to "compound" sputtering mode for a flow rate of $2.5 \mathrm{sccm}$ of oxygen. Deposition on silicon shows the need to work in "metal" mode at a flow rate close to the transition to obtain a stoichiometric crystallized YSZ with very high deposition rates $\left(>10 \mu \mathrm{m} \cdot \mathrm{h}^{-1}\right)$ compared to those reported in literature. Although these deposits are columnar, they appear compact according to SEM observations. Coatings on NiO-YSZ anode commercial exhibit the same properties: in addition, the film follows the complexity of the substrate (roughness and porosity) to form a compact and covering layer. Annealing treatments on air or hydrogen atmosphere do not significantly alter the structure of the layers. SOFC complete cell were designed in commercial NiO-YSZ anode supported configuration: YSZ electrolyte was deposited by magnetron sputtering, whereas cathode (platinum or lanthanum strontium manganite) was screen painted. A LSM-based cathode is more efficient than a Pt one. All the configurations are gastight enough to be analyzed. At $850^{\circ} \mathrm{C}$, the maximum power reaches $350 \mathrm{~mW} . \mathrm{cm}^{-2}$ with an ASR of $0.6 \Omega \cdot \mathrm{cm}^{-2}$ which are comparable to commercial device. 


\section{Acknowledgements}

The authors wish to acknowledge the "Région CENTRE" for financial support (APR ELECTROLYTE). 


\section{References}

[1] A. Kirubakaran, S. Jain, R. Nema, Renew. Sust. Energ. Rev. 2009, 13, 2430

[2] N.Q. Minh, J. Am. Ceram. Soc. 1993, 76, 563

[3] J. W. Fergus, J. Power Sources 2006, 162, 30

[4] A. Evans, A. Bieberle-Hütter, J. L. Rupp, L. J. Gauckler, J. Power Sources 2009, 194, 119

[5] B.C. Steele, A. Heinzel, Nature 2001, 414, 345

[6] L. Zhao, X. Huang, R. Zhua, Z. Lua, W. Sun, Y. Zhanga, X. Gea, Z. Liu, W. Su, Journal of Physics and Chemistry of Solids 2008, 69, 2018

[7] X. Wang, A. Atkinson, Acta Materialia 2011, 59, 2514

[8] K.C. Wincewicz, J.S. Cooper, J. Power Sources 2005, 140, 280

[9] K. Wasa, M. Kitabatake, H. Adachi, H. Thin Film Materials Technology: Sputtering of Compound Materials, William Andrew Inc. 2004 pp537

[10] P. Briois, A. Billard, Surf. Coat. Tech. 2006, 201, 1328

[11] H. Hidalgo, E. Reguzina, E. Millon, A.L. Thomann, J. Mathias, C. Boulmer-Leborgne, T. Sauvage, P. Brault, Surf. Coat. Tech. 2011, 205, 4495

[12] A. Shaula, J. Oliveira, V. Kolotygin, C. Louro, V. Kharton, A. Cavaleiro, Vacuum 2009, 83, 1266

[13] E. Rezugina, A.L. Thomann, H. Hidalgo, P. Brault, V. Dolique, Y. Tessier, Surf. Coat. Tech. 2010, 204, 2376

[14] C.L. Chu, J.-Y. Wang, S. Lee, Int. J. Hydrogen Energ. 2008, 33, 2536

[15] M. Mayer, K. Arstila, K. Nordlund, E. Edelmann, and J. Keinonen, Nucl. Instr. Meth. B 2006, 249, 823

[16] N.Q. Minh, J. Am. Ceram. Soc. 1993, 76, 563

[17] S.Venkataraj, O.Kappertz, H. Weis, R. Drese, R. Jayavel, M.Wuttig, J.Appl. Phys. 2002, 92, 3599

[18] D. Depla, S. Heirwegh, S. Mahieu, J. Haemers, R. D. Gryse, J. Appl. Phys. 2007, 101, 013301

[19] R. Snyders, M. Wautelet, R. Gouttebaron, J.P. Dauchot, M. Hecq, Thin Solid Films 2003, 423, 125

[20] H.Wang, W. Ji, L. Zhang, Y. Gong, B. Xie, Y. Jiang, Y. Song, Solid State Ionics 2011, 192, 413

[21] T. Hata, K. Sasaki, Y. Ichikawa, K. Sasaki, Vacuum 2000, 59, 381

[22] A.F. Jankowski, J.P. Hayes, Surf. Coat. Tech. 1995, 76-77, 126-131

[23] A. Yamamoto, Y. Abe, M. Kawamura, K. Sasaki, Vacuum 2002, 66, 269

[24] R. Snyders, R.Gouttebaron, J.P. Dauchot, M. Hecq, J. Anal. At. Spectrom. 2003, 18, 618

[25] S.Venkataraj, O. Kappertz, H. Weis, R. Drese, R. Jayavel, M.Wuttig, J.Appl. Phys. 2002, 92, 3599

[26] J.F. Ziegler, M.D. Ziegler, J.P. Biersack, Nucl. Instr. And Meth. B 2010, 268, 1818

[27] David R. Lide, CRC Handbook of Chemistry and Physics, 87th Edition, Taylor and Francis, pp 2388

[28] L. Vegard, Zeitschrift für Physik 1921, 5, 17

[29] A. Palenzona, S. Cirafici, J Phase Equilib. 1991, 12, 485

[30] J.A. Krogstad, M. Lepple, Y. Gao, D.M. Lipkin, C.G. Levi, J. Am. Ceram. Soc. 2011, 1

[31] H.Wang, W. Ji, L. Zhang, Y. Gong, B. Xie, Y. Jiang, Y. Song, Solid State Ionics 2011, 192, 413

[32] P. Coddet, M.C. Pera, A. Billard, Fuel Cells 2011, 11, 158

[33] R. Nédélec, S. Uhlenbruck, D. Sebold, V.A.C. Haanappel, H.P. Buchkremer, D. Stöver , Journal of Power Sources 2012, 205, 157 


\section{Table Captions}

Table $1 \mathrm{OCV}$, maximum power and area specific resistivity (ASR) and current density at $700 \mathrm{mV}$ of tested cells

\section{Tables}

Table 1

\begin{tabular}{|c|c|c|c|c|c|c|c|c|}
\cline { 2 - 9 } \multicolumn{1}{c|}{} & \multicolumn{2}{c|}{\begin{tabular}{c} 
OCV \\
\multicolumn{1}{c|}{}
\end{tabular}} & \multicolumn{2}{c|}{$\begin{array}{c}\text { Pmax } \\
{[\mathrm{mW}]}\end{array}$} & \multicolumn{2}{c|}{$\begin{array}{c}\mathrm{j} @ 700 \mathrm{mV} \\
{\left[\mathrm{mA}^{-2}\right]}\end{array}$} & \multicolumn{2}{c|}{$\begin{array}{c}\text { ASR } @ 700 \mathrm{mV} \\
{\left[\Omega . \mathrm{cm}^{-2}\right]}\end{array}$} \\
\cline { 2 - 9 } & $800{ }^{\circ} \mathrm{C}$ & $850{ }^{\circ} \mathrm{C}$ & $800^{\circ} \mathrm{C}$ & $850^{\circ} \mathrm{C}$ & $800^{\circ} \mathrm{C}$ & $850{ }^{\circ} \mathrm{C}$ & $800{ }^{\circ} \mathrm{C}$ & $850{ }^{\circ} \mathrm{C}$ \\
\hline YSZ/Pt & - & 977 & - & 120 & - & 113 & - & 2.06 \\
\hline YSZ/LSM & 985 & 995 & 239 & 350 & 267 & 404 & 1.31 & 0.62 \\
\hline
\end{tabular}

\section{Figure Captions}

Fig. 1 Magnetron sputtering device

Fig. 2 SOFC test device

Fig. 3 (a) Target voltage and (b) chamber pressure versus the oxygen flow rate. Square [triangle] symbols correspond to an increasing [decreasing] oxygen flow rate. The full [empty] symbols correspond to the "metal" ["compound"] mode behavior. The dotted line on the pressure curve corresponds to the pressure without plasma

Fig. 4 Influence of oxygen flow rate on the $750 \mathrm{~nm}$ argon line intensity (normalized by its maximum) and on the intensity ratio of each species; the full [empty] symbols correspond to an increasing [decreasing] oxygen flow rate.

Fig. 5 Deposition rate according to the oxygen flow rate

Fig. 6 Surface and cross-section morphology of the YSZ films according to oxygen flow rate

Fig. 7 (a) Substitution rate (x) of xYSZ and (b) oxidation level $(\Omega)$ of deposited YSZ thin films versus oxygen flow rate

Fig. 8 XRD pattern of thin films according to oxygen flow rate. $11 \mathrm{YSZ}$ (circle), $\mathrm{t}-\mathrm{ZrO}_{2}$ (arrow), $\mathrm{Zr}: \mathrm{Y} 76 / 24$ solid solution (diamond) peaks position are reported

Fig. 9 Surface and cross-section morphology of the coating on anode after deposition, after air annealing and after $\mathrm{H}_{2}$ reduction

Fig. 10 SEM cross section observation of SOFCs assemblies: (a) platinum cathode based cell and (b) LSM cathode based cell

Fig. 11 SOFC test of a magnetron sputtering YSZ electrolyte: (a) measured voltage and (b) calculated power density in a function of current density 


\section{Figures}

Fig. 1

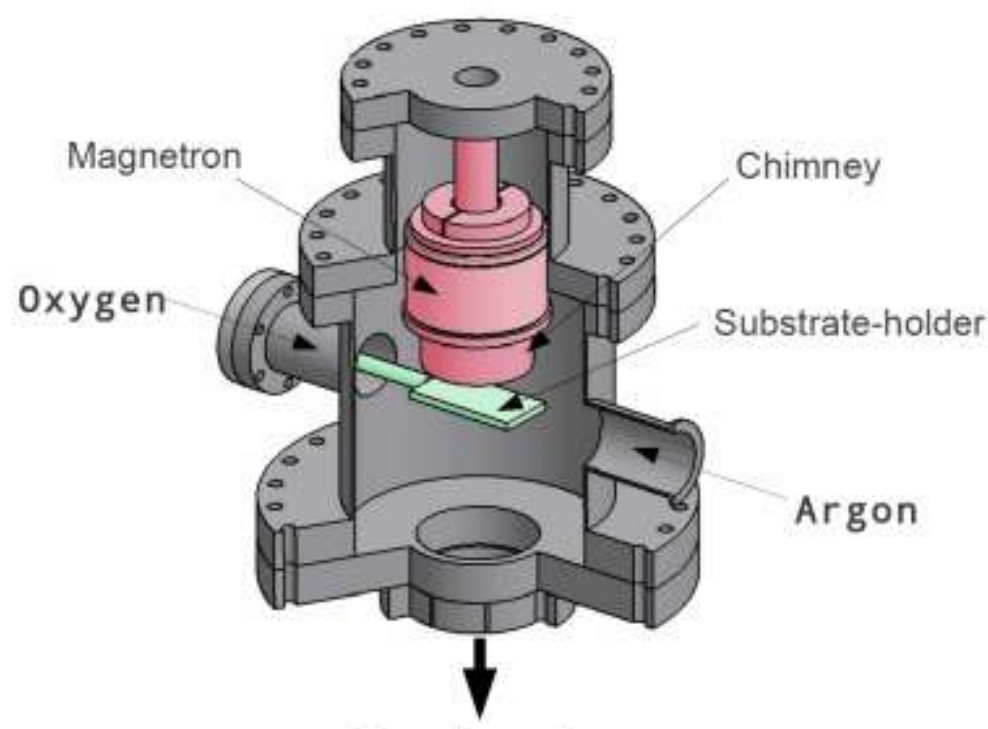

Pumping system

Fig. 2

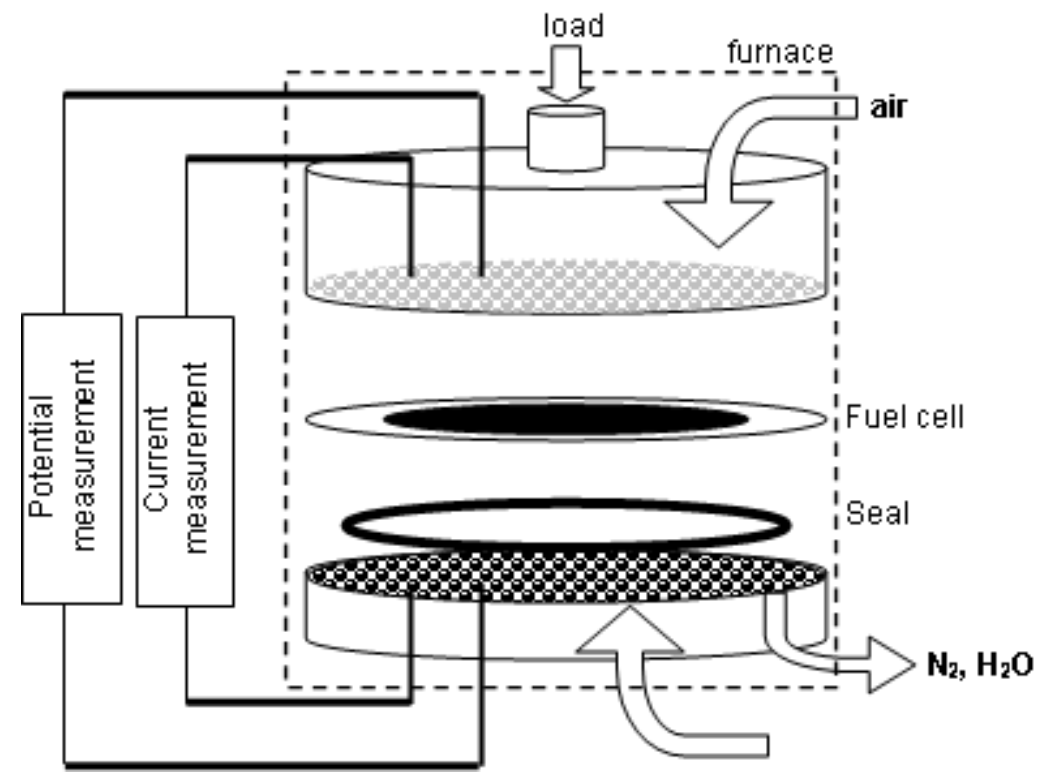


Fig. 3(a)

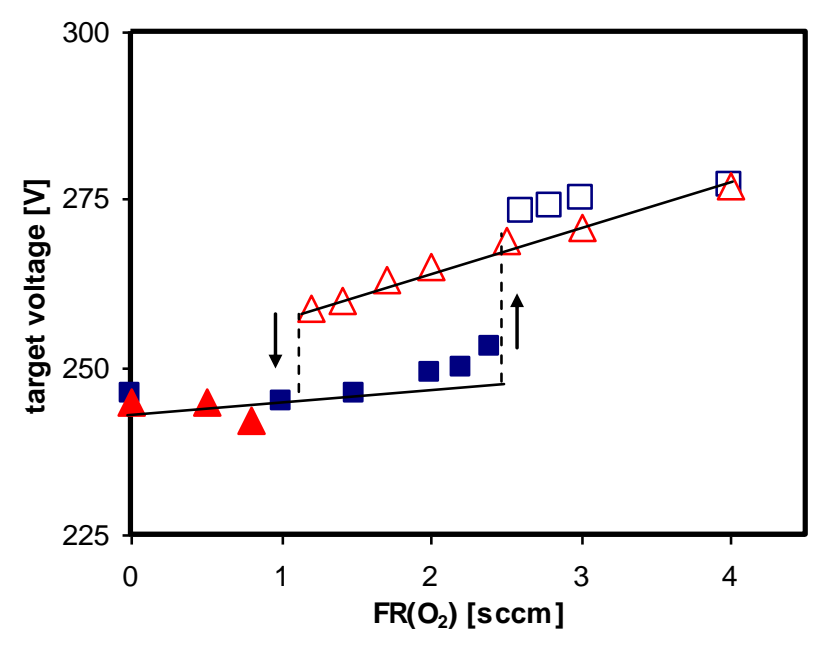

Fig. 3(b)

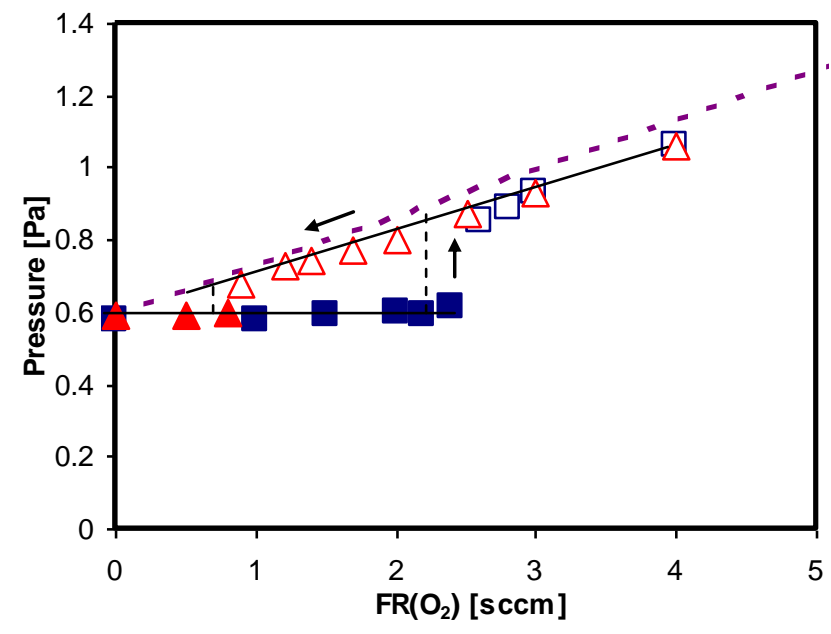


Fig. 4
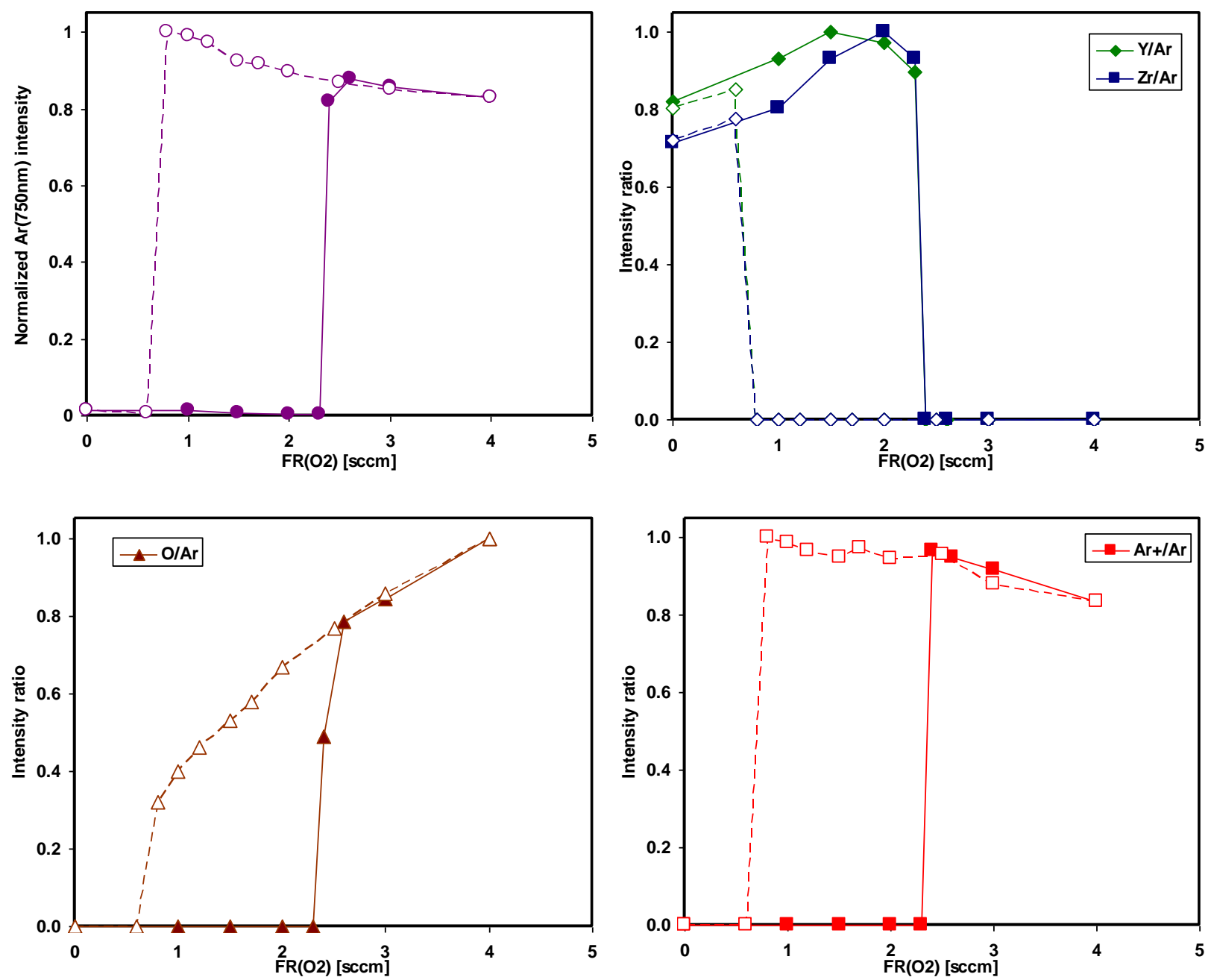
Fig. 5

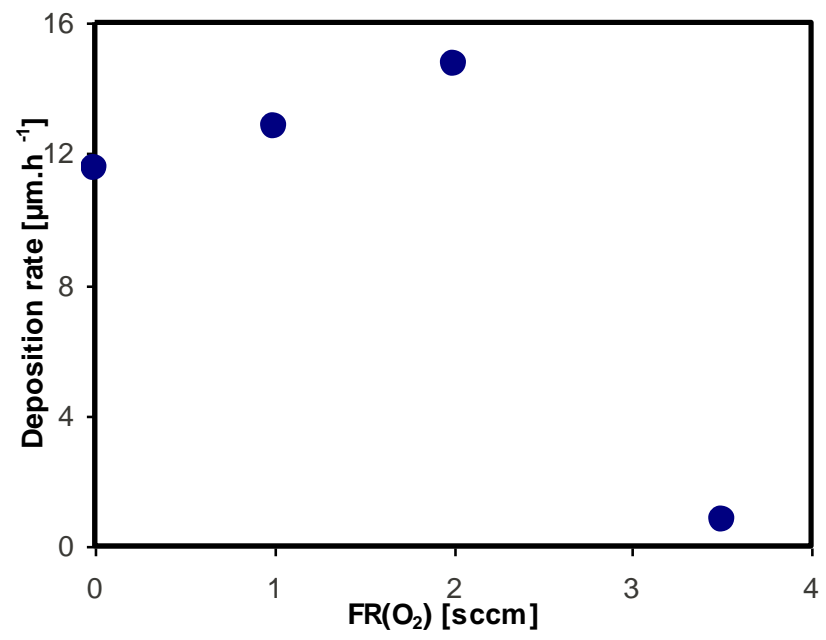

Fig. 6

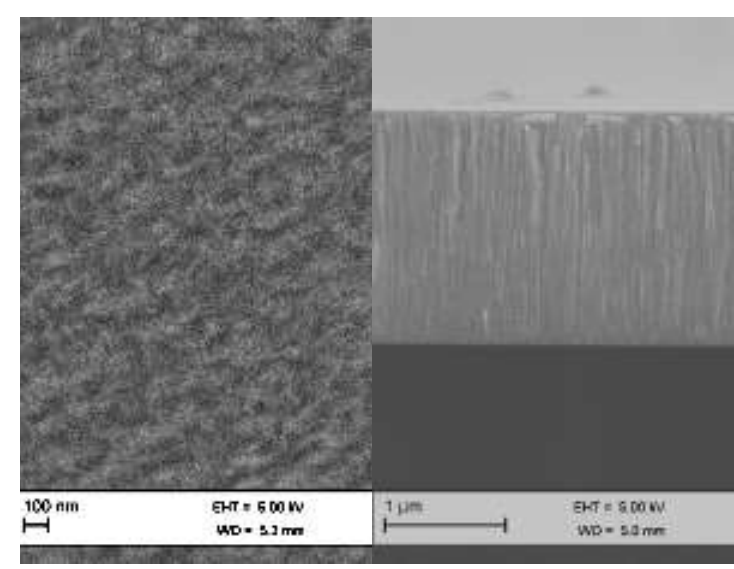

$0 \mathrm{sccm}$

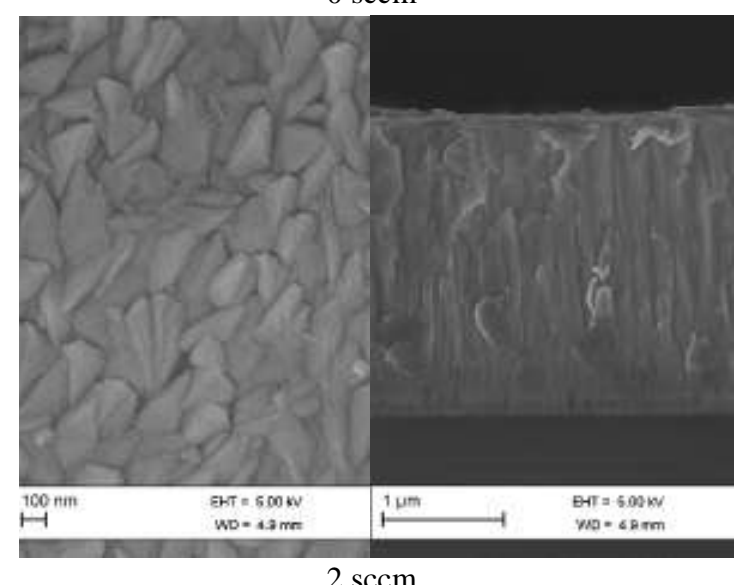

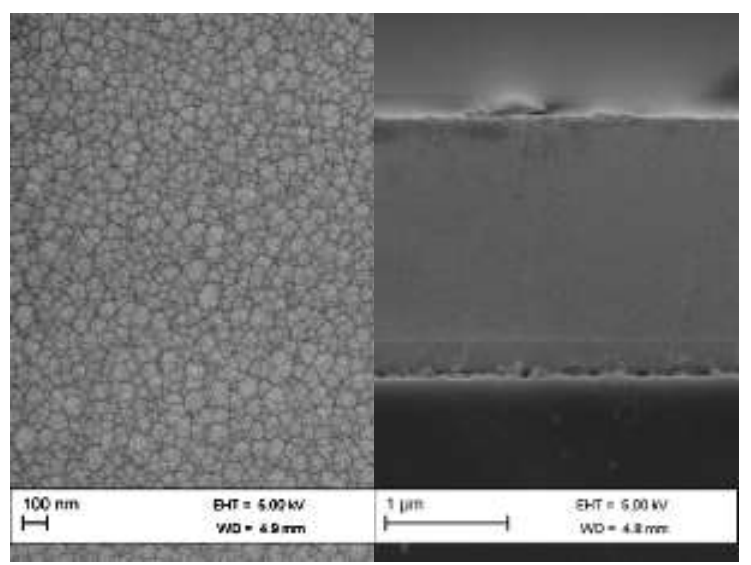

$1 \mathrm{sccm}$

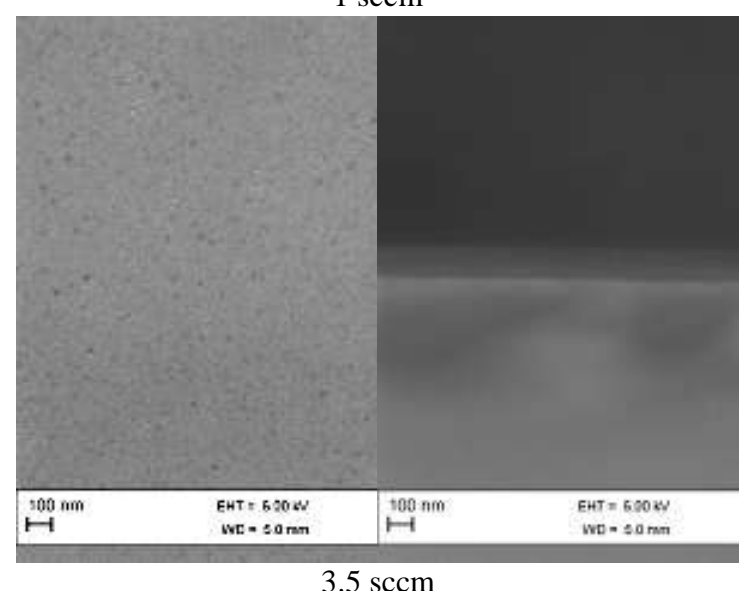


Fig. 7(a)

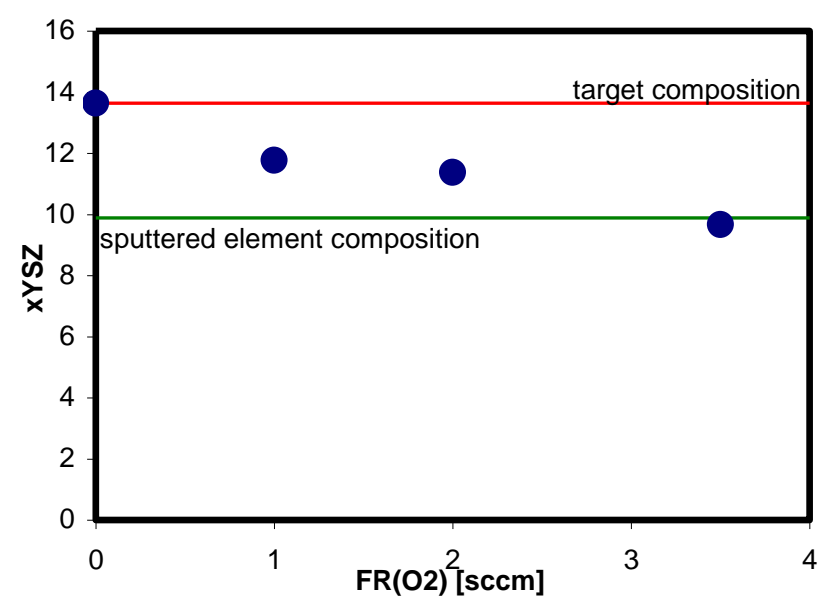

Fig. 7(b)

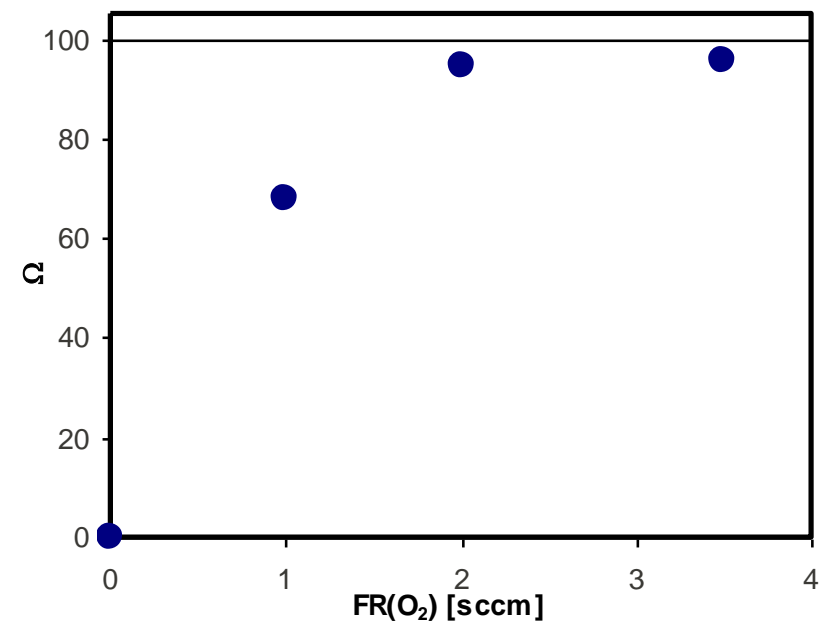


Fig. 8

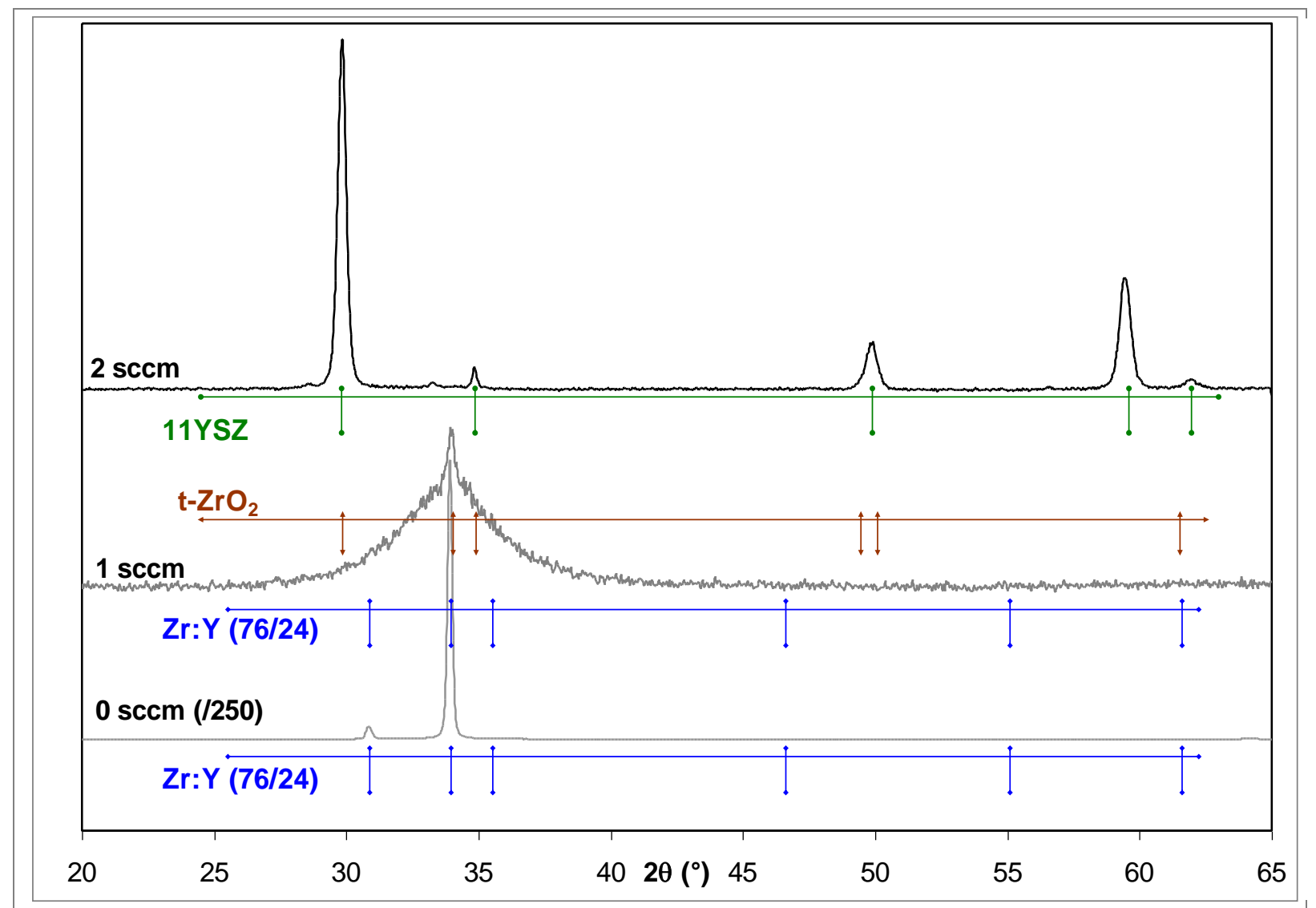

Fig. 9

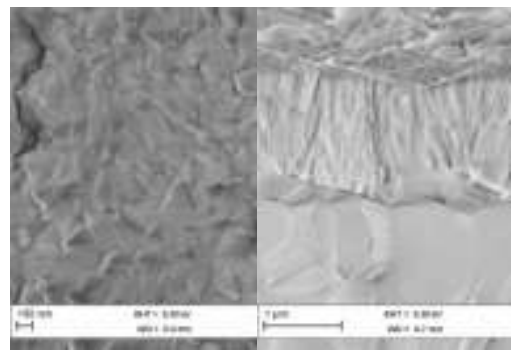

As deposited

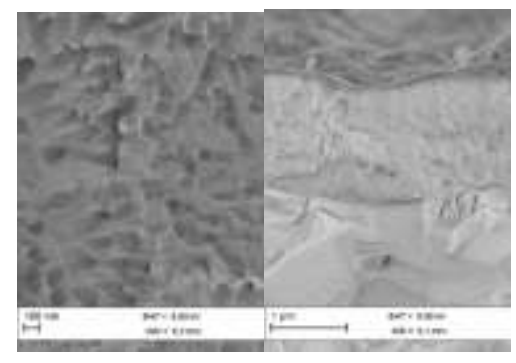

After $\mathrm{O}_{2}$ annealing

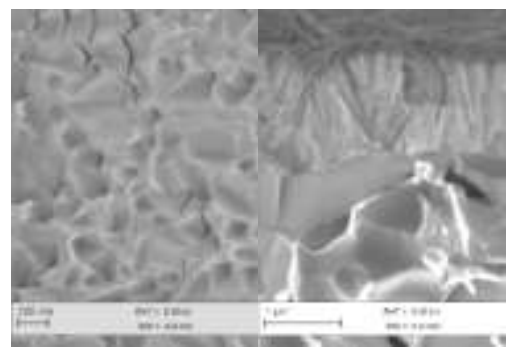

After $\mathrm{H}_{2}$ annealing

Fig. 10

Platinum cathode

YSZ thin film electrolyte

NiO-YSZ anode

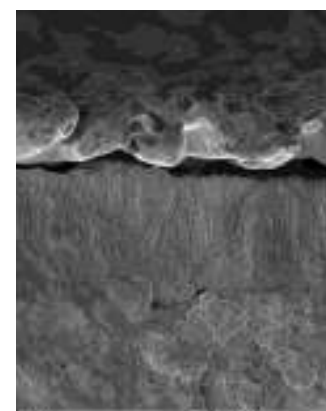

mo.

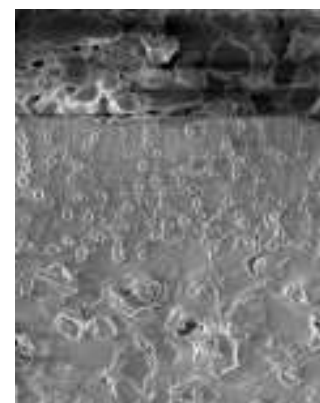

LSM cathode

YSZ thin film

electrolyte

NiO-YSZ anode
澏 ort

(


Fig. 11(a)

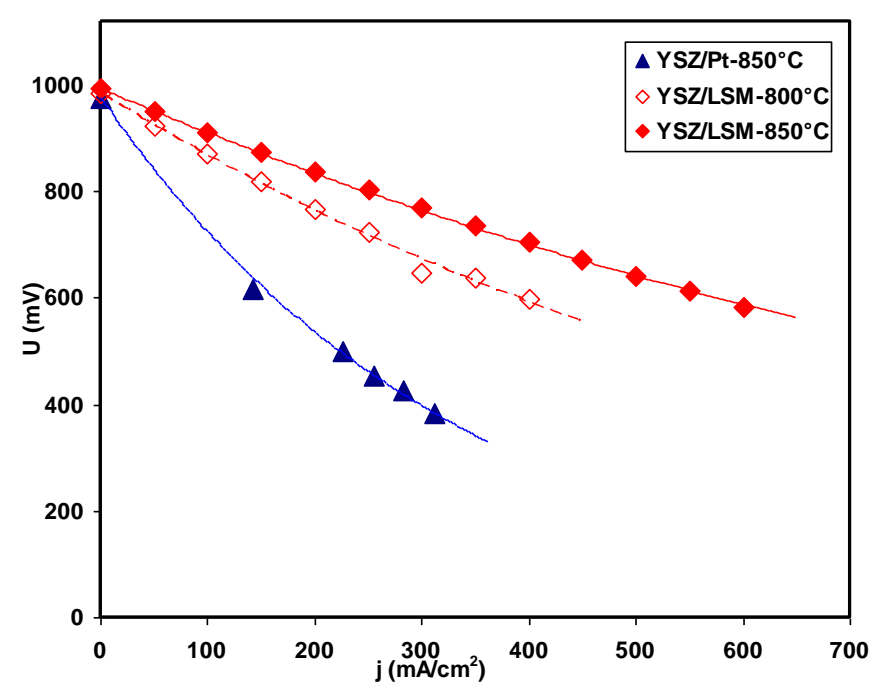

Fig. 11(b)

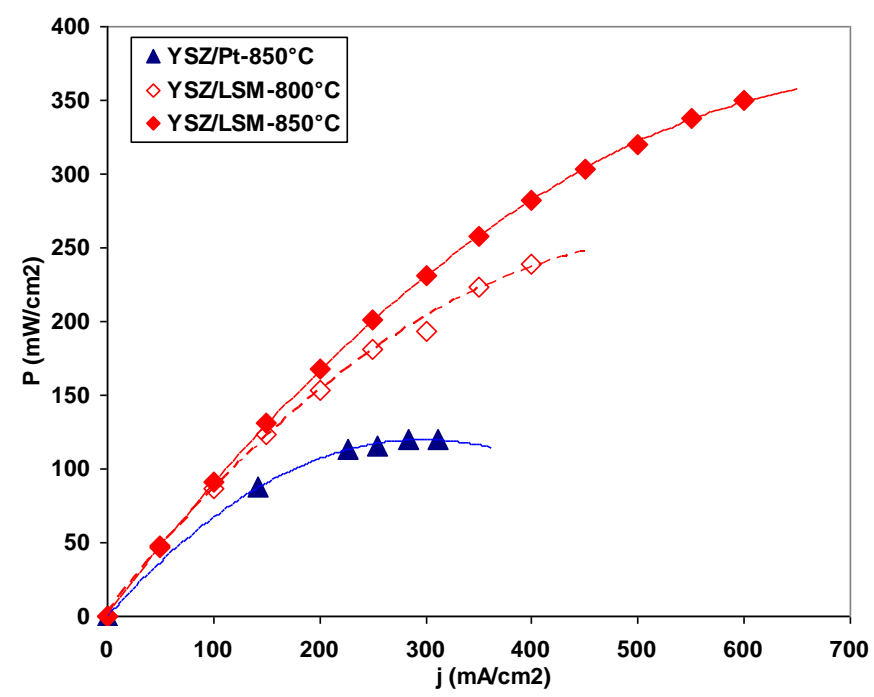

